Article

\title{
Design of Evaluation Scheme for Social Responsibility of China's Transportation Enterprises from the Perspective of Green Supply Chain Management
}

\author{
Jiaqi Luo ${ }^{1,2}$, Mingxiao Bi ${ }^{1}$ and Haibo Kuang ${ }^{1,2, *}$ \\ 1 Collaborative Innovation Center for Transport Studies, Dalian Maritime University, Dalian 116026, China; \\ luojiaqi2019@dlmu.edu.cn (J.L.); Tougao2020@dlmu.edu.cn (M.B.) \\ 2 School of Shipping Economics and Management, Dalian Maritime University, Dalian 116026, China \\ * Correspondence: Khb@dlmu.edu.cn; Tel.: +86-0411-8472-8486
}

Citation: Luo, J.; Bi, M.; Kuang, H. Design of Evaluation Scheme for Social Responsibility of China's Transportation Enterprises from the Perspective of Green Supply Chain Management. Sustainability 2021, 13, 3390. https://doi.org/10.3390/ su13063390

Academic Editor: Andrea Appolloni

Received: 4 February 2021

Accepted: 16 March 2021

Published: 18 March 2021

Publisher's Note: MDPI stays neutral with regard to jurisdictional claims in published maps and institutional affiliations.

Copyright: (c) 2021 by the authors. Licensee MDPI, Basel, Switzerland. This article is an open access article distributed under the terms and conditions of the Creative Commons Attribution (CC BY) license (https:// creativecommons.org/licenses/by/ $4.0 /)$.

\begin{abstract}
Corporate social responsibility (CSR) in the supply chain has become an increasingly popular research topic, but there are little researches on developing countries or emerging market economies as the research object, let alone providing a framework for assessing CSR in sustainable supply chains in the context of these countries. This paper will make up for these literature gaps. From the perspective of the green supply chain management, this paper integrates various authoritative standards and adopts two methods, "R clustering" and "variation coefficient analysis", to establish a CSR performance evaluation system of China's transportation industry. Applying the mean square error index weighting method analyzes the performance of 74 companies in China's transportation industry in 2018 to verify the rationality of the evaluation system. The results find that this industry generally scores low and the performance of responsibilities of different sub-sectors in this industry is different, but the overall performance trend is improving. This research has implications for China's transportation industry to improve CSR levels from the perspective of green supply chain management, for managers and stakeholders who are committed to improving China's CSR green and sustainable development, and for the development of CSR in developing countries and emerging markets.
\end{abstract}

Keywords: corporate social responsibility; R-clustering model; green supply chain management; transportation industry

\section{Introduction}

Corporate social responsibility (CSR) has become a topic of widespread concern in business and academic research. It is worth noting that with the deepening of CSR practice, international social responsibility has gradually shown the characteristics of standardization and rigid constraints. Since the 1990s, authoritative organizations around the world began to research and publish a relatively mature CSR performance evaluation system that was applied to the world. Representative ones are Domini Social Index [1], Global Compact [2], Social Accountability 8000 International Standard (SA8000) [3], International Standard Organization 26,000 Social Responsibility Guide (ISO26000) [4], Global Reporting Initiative Sustainability Reporting Guidelines (GRI4.0) [5]. Most of the western CSR performance evaluation studies take these mature CSR performance evaluation systems as the standard research framework. However, despite the increasing focus on CSR in western developed economies in recent years, the awareness of CSR in Asia is quite low at both the company level and the state level [6], and China is Asia's largest developing country and emerging market economy. Compared with the current increasingly important international status, China's attention and research on CSR are very limited, and the social responsibility awareness of Chinese companies is relatively low. To a large extent, this is because China's main policy since the 1990s has been to vigorously develop the economy 
and has neglected social responsibilities while the economy is developing rapidly. It was not until China joined the World Trade Organization (WTO) in 2001 that CSR gained attention in China due to the severe situation of social irresponsibility of Chinese enterprises and foreign criticism. After that, the Chinese government and related institutions also promulgated a series of CSR reporting standards to regulate the social responsibility behavior of Chinese enterprises. In 2014, the Material and Quantitative Indicators Guideline for CSR Report (MQI) provided critical quantifications applicable to different industries in response to information disclosure issues in the compilation of CSR reports [7]. Chinese National Standards for Guidance on Social Responsibility Reporting (GSR) issued in 2015 provided the basic criteria, steps, and methods for compiling social responsibility reports [8]. In 2014, the Environmental, Social and Governance Reporting Guidelines of the Hong Kong Stock Exchange (ESG) listed the main categories, levels, general disclosures, and key performance indicators, which are related to environmental, social, and governance areas [9].

CSR continues to evolve in practice, and its reach now often extends to supply chain partners. CSR in the supply chain has gradually become a research topic that scholars are interested in. In recent years, companies have realized the importance of working with supply chain partners to improve their reputation and CSR performance [10]. Especially, in Nike's sweatshop incident, Nike failed to assume the social responsibility of its supply chain partners in the early stage, which affected its reputation and corporate performance [11]. Therefore, scholars and managers began to consider how to manage social responsibility issues in the supply chain to improve corporate performance, such as by formulating and implementing codes of conduct to solve them [12-14]. Hervani and Helms propose to propose a framework for measuring and reporting SSCM practices to solve this problem [15]. Although scholars have made valuable contributions to the SSCM framework and supply chain corporate social responsibility, the following literature gaps cannot be ignored. First, there is a lack of practical and standardized modeling research in this field. Moreover, some of the evaluation frameworks adopt more subjective evaluation methods, which lack objectivity and persuasiveness [16]. For example, Reefke and Sundaram researched the field of sustainable supply chain management through exploratory Delphi research [17]. This empirical summary method is not persuasive and may not apply to all situations. Second, although scholars have constructed supply chain social responsibility evaluation models and frameworks from different aspects and industries, their current research fields focus on the consumer goods industry or various Services and manufacturing [18-20]. Finally, taking developing countries or emerging market economies as the object, there are very few evaluation frameworks to build sustainable supply chain social responsibility [16].

The main objective of this paper is to establish a CSR evaluation system suitable for China's transportation industry by combining the ideas of the green supply chain management, to bridge the literature gap between developing countries or emerging market economies and the transportation industry in terms of CSR in green supply chain. Particularly, this paper will combine the above-mentioned domestic and foreign standards of CSR and the actual situation of enterprises in China's transportation industry and use the method of "R-clustering + coefficient of variation" and the mean square deviation weighting method to establish the evaluation system and apply it in practice. Therefore, the specific goals of this paper (1) aim at the major industry needs of China's Ministry of transport to comprehensively and deeply promote the development of green transportation and green logistics, guided by the "outline for the construction of a transportation power", based on the perspective of green supply chain management, in contrast to the theoretical frontier and innovative practice of the development of international corporate social responsibility, based on the characteristics of China's transportation industry, combined with ISO26000 and GRI4.0 and other domestic and foreign authoritative corporate social responsibility, the first social responsibility evaluation system for China's transportation industry has been constructed. (2) This paper applies the obtained evaluation system to different companies in the transportation industry of China in 2018, to facilitate different types of 
companies in the industry the comparison between them, as well as the determination of the rationality of the evaluation system. By constructing a more reasonable CSR evaluation system for China's transportation enterprises, we will promote transportation enterprises to better fulfill their corporate social responsibilities and promote the sustainable and green development of the Chinese transportation industry.

This study is mainly divided into the following parts. First, the literature review describes the relevant theories of CSR and green supply chain management. Secondly, the section of materials and methods introduces the principles and methods of constructing the CSR evaluation system. The third part is the results and discussion, applying the theory to practice, verifying and analyzing the scientificity, rationality, and innovation of the CSR evaluation system obtained. In the last part, the thesis is summarized, and the limitations of the research and the prospect of future research are clarified.

\section{Literature Review}

\subsection{Corporate Social Responsibility}

Since the 1950s, the academic field has been increasingly studying CSR. Although there is a lot of research on CSR, the academic circles have not reached a consensus on the definition of CSR. For example, Dao and others believe that CSR is a company's commitment to operating economic, social, and environmental sustainability [21]. Vidal et al. believe that CSR "is a concept that is difficult for companies to explain and implement", because it involves the integration of internal organizations or the rearrangement of business practices and procedures that reflect environmental, social, and ethical issues and may or may not be developed in the supply chain with stakeholders [22]. Although different scholars have different opinions on the definition of CSR, there are generally two trends that can be accepted by everyone: one is related to social management issues, such as the Triple Bottom Line (TBL) proposed by Elkington, and the other is Related to stakeholders, such as Whitten, etc. [23-25]. This can also reflect that stakeholders play an important role in CSR practice. Stakeholder refers to any individual or group that can influence or be affected by the goals of the enterprise [26]. Executives or entrepreneurs need to handle and manage the relationships among customers, suppliers, employees, financiers (shareholders, bondholders, banks, etc.), communities, and managers to create value for the company [27]. This is consistent with the views of Ackermann and Eden, who believe that the senior management team should pay attention to the important concepts that appear in the stakeholder literature to improve the robustness of its strategy [28]. At the same time, investors believe that the decision to participate in CSR is an indicator of future financial performance growth, because consumers tend to support CSR practices, and they tend to buy products and services from socially responsible companies at the same price and quality [29]. Therefore, Egbeleke believes that companies not only need to comprehensively consider economic, social, and environmental factors when formulating the company's overall strategy but also must thoroughly consider the impact of their CSR projects on organizational performance and stakeholder activities [30]. Usually, companies communicate with stakeholders by disclosing corporate social responsibilities and respond to their expectations to prove that the company is responsible for society and the environment and that its behavior follows social values [31]. The main purpose of the company's disclosure of social responsibility information is to show the image of social responsibility so that they can legitimize their actions to stakeholder groups and affect the reputation of external stakeholders [32]. Generally, companies will participate in some form of stakeholder management for two motivations [32]. One is based on a resource point of view. If a company participates in CSR disclosure to show that it operates in accordance with social and ethical standards, it can consolidate the trust of stakeholders and establish a good corporate image, thus bringing more competitive advantages and economic benefits to the company. The other is to engage in CSR activities and disclosure to avoid corporate risks due to external pressure. If not, it may lose this reputation value [33]. Besides, there is evidence that through empirical research on Italian family businesses, Gavana et al. found that when companies are characterized by consumer 
proximity, in terms of consumers' visibility of products and services, CSR disclosure has a significant impact on corporate income [34].

Stakeholder theory is often applied to the research of CSP theory (Corporate Social Performance). Unlike CSR, for some scholars, CSP is seen as a "pragmatic approach" to CSR because it "tries to model and measure social responsibility based on performance" [35] (pp.110). However, according to the definition first described by Carroll (1979), CSP is a three-dimensional integration of CSR, corporate social response, and social issues, and the concept of corporate social performance includes CSR [36]. Moreover, due to the multidisciplinary nature of measuring the different behaviors and methods displayed by CSP, the measurement of CSP will consider multiple dimensions and provide a clearer understanding of CSR viewpoints [37-39]. The CSP model relies on this extended version of social responsibility and this principle/process/policy method to provide a unique perspective for the overall efforts of enterprises to fulfill their social obligations [40]. Obviously, as with CSR research, different stakeholders must also be considered when measuring CSP. Colle believes that measuring CSP must include quantifying employee working conditions, harmful emissions, relationships with key stakeholders (such as shareholders, customers, suppliers, employees, and local communities), and a wide range of other social and environmental indicators [41]. Some scholars combine stakeholder theory to measure CSP using a variety of methods and propose many valuable CSP models. For example, based on the stakeholder theory, Crian-Mitra et al. propose a summary model of responsible management behavior and a CSP evaluation framework for large emerging market companies [42]. Chang and Yeh also combine the views of internal and external stakeholders, using the analytic hierarchy process and decision-making laboratory methods to measure the social responsibility performance of Taiwan Taoyuan International Airport [43].

Besides, current research on CSR/CSP will also pay more attention to the impact on performance. Performance is now described as a multidimensional concept, including financial and non-financial aspects, and covers the interests of all stakeholders [44,45]. Some scholars say that CSR practices can improve a company's business performance, while others deny or neutralize or state that its impact is difficult to measure [37,46-51]. At the same time, it should be noted that social responsibility may have different results on performance in the context of emerging markets. For example, Brik et al. believe that in the context of emerging economies, CSR has a synergistic effect on the impact of market orientation on corporate performance. Although CSR regulates the relationship between customer orientation and corporate performance, it does not regulate the relationship between competition orientation and inter-functional coordination and performance [52]. Zhao et al. study China's Shanghai and Shenzhen A-share listed companies from 2009 to 2016 and find that in the short term, the company's CSR report had no obvious impact on the efficiency of capital allocation, but in the long run, it can improve the efficiency of capital allocation [53]. Some scholars also use the transportation industry as the research object to study the impact of CSR on corporate performance. Evidence shows that the performance of CSR in the transportation industry has an obvious positive effect on the current financial performance indicators, and financial performance will be positively affected by both the lagging period and the lagging two periods of CSR [54]. This shows that the CSR evaluation system of China's transportation industry to be created in this paper has a positive impact on the performance of the industry, and the research in this paper will generate theoretical and practical value. The next part will review the literature on specific methods, models, and evaluation systems of CSR evaluation.

\subsection{The Corporate Social Responsibility Evaluation System}

The implementation of CSR development framework and formal tools is an important research method in the field of social responsibility [55]. Just like Vidal, such tools usually include codes of conduct, policies that address specific issues such as the social environment that companies face, key performance indicators and monitoring of social and environmental behavior, and CSR reports [22]. Researchers have also made a lot of ef- 
forts in the above aspects. The social participation disclosure indicator system constructed by Abbott and Monsen inspires CSR practices [56]. Moreover, Carroll's framework of CSR pyramid including economy, law, ethics, and charity also prompts companies to reconfigure business strategies oriented to the environment and society [36]. However, for the evaluation of CSR/CSP, sometimes a certain model and framework established by a single theory and method may not be suitable for all complex situations. The use of a comprehensive model may allow all stakeholders to pay attention to the CSR practices in daily business [57]. Therefore, researchers learn from international authoritative standards, such as SA8000, ISO2600, GRI4, United Nations Convention Framework, etc., and try to adopt different methods and construct comprehensive CSR/CSP models from different dimensions to enrich related models research. For example, Costa and Menichini, based on the balanced scorecard (BSC) perspective and sustainability dimensions, use the Global Reporting Initiative (GRI) indicator framework to establish a multi-dimensional model of CSR evaluation, which assesses and analyzes CSR activities in the eyes of stakeholders [58]. Wang et al. borrow from the leading framework of the United Nations (UN) and adopt a mixed multi-criteria decision-making (MCDM) method to propose a CSR model that can alleviate potential information asymmetry problems and improve corporate performance [59].

It needs to be realized that the application of the CSR/CSP framework and model may also be different due to differences in the cultural systems of different economies and different countries $[60,61]$. Chinese scholars are also trying to use different theories and methods to establish a CSR evaluation model suitable for China's national conditions. Chen et al., based on the practice of Chinese CSR, combined with the triple bottom line and stakeholder theory, construct a detailed, comprehensive, and authoritative Chinese CSR evaluation model [62]. Although the transportation companies are also given specific scores, this industry has not been analyzed in detail, including the comparison between its sub-sectors, which cannot be well demonstrated. Later, some scholars use a variety of comprehensive methods to construct the CSR evaluation system of China's transportation industry and compare and analyze the performance of the sub-sectors involved. For example, Qi et al. use "R clustering and coefficient of variation analysis" to screen indicators and construct the CSR evaluation system of China's transportation enterprises with seven standard levels, including responsible governance, human rights, environment, fair operation, product responsibility, community development, and economic contribution [63]. On the other hand, Meng Bin adopts the main basic analysis and related analysis methods to establish a CSR evaluation index system for China's transportation industry, including 6 first-level standard levels, 12 s-level standard levels, and 39 indicators [64]. However, neither the CSR framework nor the evaluation system established by scholars emphasizes the importance of green supply chain management. The research in this paper will bridge this literature gap. The next part will review the relationship between supply chain management and CSR, as well as the evaluation methods and evaluation models of supply chain corporate social responsibility.

\subsection{Corporate Social Responsibility and Green Supply Chains Management}

A supply chain is a set of organizations that involve upstream and downstream processes of products, services, and finance, and the flow of information from initial suppliers to channel members to end-users or customers $[65,66]$. By this definition, the supply chain involves multiple organizations and many stakeholders, so it is particularly important to handle these relationships well. There is evidence that the integration of practices and policy consistency between supply chain partners affects the final performance of the organization [67]. Customers and organizations operating in the supply chain must rely on and trust each other to achieve their ultimate goals [68]. In the business environment within and between organizations, this integration of supply-demand relationship management is often referred to as supply chain management [69]. The advantage of supply chain management lies in the effective operation of every organization in the supply chain that 
participates in value delivery through value-added channels, and in this process, these organizations have a stronger cooperative relationship, and thus, in their respective supply chains, they obtain a higher level of efficiency in operation than the individual independent competition [70-73].

Besides, it should be noted that sustainable development strategies play an increasingly important role in enterprise supply chain management. Many scholars have turned to research on green sustainable supply chain management to improve the environmental performance of the entire supply chain. Unlike traditional supply chain management, sustainable (green) supply chain management (SSCM) requires detailed consideration of the economic, ecological, and social aspects of business practices [74]. Environmentally sustainable supply chain management (GSCM) not only can reduce environmental risks and impacts, improving the ecological efficiency of these organizations and their partners, but can also help achieve company profit and market share goals [75]. The current research on green sustainable supply chain management (GSCM) is mainly focused on reducing the impact on the environment through effective design or energy use and considers the social impact on individuals, communities, and wildlife, as well as the commercial impact on profitability [76]. For example, in the design of a reverse supply chain network for a used car resale company, Thank Sathiya et al. propose a mobile robot-solar automated guided vehicle (AGV) strategy and a new multi-objective optimization model strategy to reduce logistics costs and reduce greenhouse gases emission [77]. They fully consider social, economic, and ecological goals in the design of green supply chain management, which not only helps the company improve efficiency and social attention but also promotes environmental sustainability and increases social benefits.

Although supply chain practitioners have been slow to adopt CSR considerations, the concept of social responsibility in the supply chain is becoming more and more important [78]. The consideration of social responsibility in the supply chain can be traced back to Poist, who adds social issues to the traditional economic driving force of the supply chain [79]. After that, many scholars analyze the types and characteristics of supply chain social responsibility from various aspects through different empirical studies and emphasize the importance of social responsibility in the supply chain $[18,80-83]$. For example, Poist points out that social responsibility in the supply chain should consider employee training, philanthropy, environment, urban renewal, workplace diversity, health and safety, and community issues such as hunger and homelessness [79]. Carter and Jennings establish business ethics-related supply chain corporate social responsibility categories based on case studies and surveys, such as business ethics, charity, community, workplace diversity, safety, human rights, and the environment $[18,80]$. Tate et al. conduct a central resonance analysis on the content of the CSR report, and conclude that the 10 major themes in the supply chain management in the CSR reports: Supply Chain, Institutional Pressure, Community Focus, Consumer Orientation, External Environment, Risk Management, Measures, Energy, Health, Green Building [84]. Some scholars have tried to summarize the elements of supply chain social responsibility suitable for all industries, such as logistics social responsibility (LSR) and procurement social responsibility (PSR), and strive to explore how to improve approaches to overall supply chain performance [80,81]. Bowrey and Clements propose a conceptual framework for reviewing the CSR performance and reporting of the entire supply chain and point out that the adoption of social auditing methods can improve the level and consistency of the CSR management and performance reporting of the supply chain and the entire supply chain organization [70]. However, most of the above studies are aimed at large global supply chain multinational companies, which makes it necessary to study different types of supply chain objects. Lindgreen et al. use Danish small and medium-sized enterprises as an example to analyze the characteristics of small and medium-sized enterprises (SMEs) that manage CSR in the supply chain [85]. Yoon et al. also find that the application of SC-CSR enhances the willingness of small and medium-sized enterprises to fulfill their social responsibilities by promoting situational needs [86]. 
In addition to analyzing the elements, characteristics, and categories of supply chain social responsibility that are suitable for various industries, the second way to explore supply chain social responsibility is to explore specific CSR issues, because different industries may have relatively unique supply chains and follow-ups and the unique SCCSR issue that comes from [87]. A single SC-CSR model is not enough to adapt the SC-CSR to the characteristics of a specific industry [88]. Scholars have also made a lot of efforts in exploring supply chain social responsibility issues in different industries. For example, Perry and Towers analyzed the inhibitors and driving factors of the implementation of corporate social responsibility in fashion supply chain management [89]. Keating et al. take banks as the research object, trying to establish a best practice model of sustainable supply chain social responsibility from the discussion [90]. Kogg conducts case studies in the textile sector and constructs a framework for CSR upstream of the supply chain [91]. Maloni and Brown have constructed a comprehensive supply chain CSR framework for the food industry, including animal welfare, biotechnology, environment, health and safety, labor and human rights, community, fair trade, and procurement in eight dimensions [88]. The above scholars' research provides a good template for exploring the supply chain social responsibility framework of specific industries. However, it is not difficult to find that this type of research rarely takes developing countries or new market economies as the background, and there is also a lack of exploration of social responsibility models and frameworks on the supply chain of the transportation industry. Therefore, it is necessary to explore a CSR evaluation model suitable for the supply chain of the transportation industry in China. It is helpful to explore the specific issues of the SC-CSR of the transportation industry, and it can also provide a reference for the SC-CSR of developing countries or emerging market economies.

\section{Materials and Methods}

\subsection{Principles of the Sea Election Index System Construction \\ 3.1.1. Construction of Evaluation System Criteria Layers}

The CSR of transportation industry in this study means that transportation enterprises should not only undertake the responsibility to shareholders, employees, consumers, environment, community, and other stakeholders but also promote the development of green, low-carbon and intelligent safety, strengthen the implementation of responsibility, improve the quality of safety management, and achieve the goal of sustainable development of transportation green supply chain. CSR has a complex hierarchical structure, which contains many elements, such as social issues, stakeholder issues, performance, etc., all of which affect the business activities of enterprises. The manifestation of CSR is the countermeasures taken by these enterprises when facing these elements. First, the important stakeholders faced by different companies are different. Second, although all companies have a common problem of social expectations, they can circumvent this common problem through the weight of different industries on the theme of "environment". Therefore, if you want to design an indicator system based on sustainable development, you should stratify the core social themes. Based on the survey of relevant information, this study combined ISO26000, GRI4.0, GB/T 36001-2015, and ESG core content design ideas and designed China's transportation industry CSR evaluation system of 7 dimensions of the standard. Eventually, they verified the reliability and validity of the indicators system through the questionnaire method. The criterion levels of these seven categories are respectively responsible governance, economic performance, environmental protection, basic human rights, product responsibility, fair operation, and community development, as shown in Table 1. 
Table 1. Classification details of each authoritative index system and proposal of the criteria level of this study.

\begin{tabular}{|c|c|c|c|c|c|}
\hline \multirow[t]{8}{*}{ Criteria } & $\begin{array}{c}\text { Material and } \\
\text { Quantitative Indicators } \\
\text { Guideline for CSR } \\
\text { Report (MQI) for the } \\
\text { Transportation and } \\
\text { Postal Industry (2012) }\end{array}$ & $\begin{array}{l}\text { The Global } \\
\text { Reporting } \\
\text { Initiative } \\
\text { Sustainability } \\
\text { Reporting } \\
\text { Guidelines } \\
\text { (GRI4.0) (2013) }\end{array}$ & $\begin{array}{c}\text { Chinese National } \\
\text { Standards for } \\
\text { Guidance on Social } \\
\text { Responsibility } \\
\text { Reporting (GSR) } \\
\text { (2015) }\end{array}$ & $\begin{array}{c}\text { The Environmental, } \\
\text { Social and } \\
\text { Governance } \\
\text { Reporting Guidelines } \\
\text { of the Hong Kong } \\
\text { Stock Exchange } \\
\text { (2018) }\end{array}$ & $\begin{array}{l}\text { The Criteria } \\
\text { Layer of the } \\
\text { Transportation } \\
\text { Industry in } \\
\text { This Study }\end{array}$ \\
\hline & Economy & Economy & $\begin{array}{l}\text { Organizational } \\
\text { Governance }\end{array}$ & $\begin{array}{l}\text { Work Environment } \\
\text { Factor }\end{array}$ & $\begin{array}{l}\text { Responsible } \\
\text { Governance }\end{array}$ \\
\hline & Environment & Environment & Human Rights & $\begin{array}{l}\text { Environmental } \\
\text { Protection }\end{array}$ & $\begin{array}{c}\text { Economic } \\
\text { Performance }\end{array}$ \\
\hline & Society & $\begin{array}{l}\text { Labor Practices } \\
\text { and Decent Work }\end{array}$ & Labor Practices & Operating Practice & $\begin{array}{c}\text { Environmental } \\
\text { Protection }\end{array}$ \\
\hline & Labor & Human Rights & Environment & $\begin{array}{l}\text { Community } \\
\text { Participation }\end{array}$ & $\begin{array}{l}\text { Basic Human } \\
\text { Rights }\end{array}$ \\
\hline & Product & Society & $\begin{array}{c}\text { Fair Operation } \\
\text { Practice }\end{array}$ & & $\begin{array}{l}\text { Product } \\
\text { Liability }\end{array}$ \\
\hline & & Product liability & Consumer Problem & & Fair Operation \\
\hline & & & $\begin{array}{l}\text { Community } \\
\text { Participation and } \\
\text { Development }\end{array}$ & & $\begin{array}{l}\text { Community } \\
\text { Development }\end{array}$ \\
\hline
\end{tabular}

\subsubsection{Interpretation of the Criteria Layers}

1. Responsible governance

The core of an enterprise is the board of directors, and the labor unions can also be said to be individuals. They control the enterprise and determine the direction of the enterprise's development. Therefore, the enterprise should establish a corresponding responsible governance organization so that social responsibility can be assumed. The lower levels include three second-level regulatory levels, including governance structure, interest-related, and responsibility response.

\section{Economic performance}

The purpose of the enterprise is to make a profit, but while creating benefits, the enterprise should also adhere to the interaction of saving resources and protecting the environment. It should not seek personal gains in unfair ways, wantonly destroy the environment, and willfully waste resources. We should adhere to sustainable development and take ensuring and improving economic quality as the ultimate goal of accelerating economic growth. There are two secondary levels of criteria, including direct economic and social contribution and indirect economic and social contribution.

\section{Environmental protection}

The business development of enterprises depends on the environment and resources, and the behaviors of enterprises will also affect the environment. Now the world is facing severe environmental problems, such as climate warming, air pollution, reduced species diversity while protecting the environment and cherishing our common homeland is the foundation of human prosperity. Therefore, enterprises should take active responsibility in pollution prevention and control, sustainable resource utilization, mitigation, and adaptation to climate change, environment, and biological diversity. Under this indicator layer, there are 4 secondary standard layers, including resource sustainability, biodiversity, pollutant discharge, environmental investment, and impact assessment.

\section{Basic human rights}

Human rights are innate, inalienable, universal, indivisible, and interdependent. Companies will directly or indirectly affect the interests of employees. The company has the responsibility to respect and protect finances within its scope of influence. The 
company's respect and protection of interests are mainly manifested in the rights to survival and development; civil and political rights; and the rights of economic, social, cultural, and other aspects. This level includes four secondary standard levels, including employee basic rights, employment relationship, health and salary benefits, and training and development.

\section{Product liability}

Consumers are the key to the survival and development of an enterprise. Whether their rights can be guaranteed determines the sustainable development of the enterprise. At present, although the country bears the burden of ensuring the interests of consumers, it needs to be implemented in the enterprise. Companies should actively assume social responsibilities in terms of consumer privacy, rights, and complaint mechanisms. The sample layer includes three secondary scale layers, including customer rights protection, product service, and supplier evaluation.

\section{Fair operation}

In today's general environment, global economic integration has reached a consensus. The international market needs a fair operation. As a link to the global supply chain, every company can also have a fair, just, and open business environment. Therefore, in business practice, companies should achieve compliance management, achieve supply chain management, respect property rights, and other aspects. There are three secondary levels of standards under this standard, including anti-corruption, compliance and a law-abiding, and appeal mechanism.

7. Community development

Enterprises exist in the community. The resources needed by the enterprise need to be provided by the community. The culture of the enterprise is also affected by the community. The operation of the enterprise in turn affects the economy, politics, culture, and even education of the community residents. The enterprise will also promote the community's development. Welfare levels can even improve the quality of life of community residents. Therefore, companies should actively seek opportunities to promote community prosperity in various aspects, such as community participation and community wealth creation. The sample layer includes four secondary regulatory layers, including community participation, health education and culture, skill development and employment, and wealth and income creation.

\subsection{Determine the Sea Election Index System}

According to the criteria of the evaluation system determined above, focusing on the high-frequency indicators of the classic views of domestic and foreign authoritative institutions, this paper combines with literature review and investigation research to conduct the audit of indicators. The principles of the indicators of the audit are according to the seven mentioned above. A first-level criterion level establishes the second-level criterion level under each criterion level. Responsible governance is divided into three second-level criteria levels: governance structure, stakeholders, and responsibility response; economic performance is divided into two second-level criteria levels: direct economic and social contributions, and indirect economic and social contributions; environmental protection is divided into four second-level criteria levels: resource sustainability, biodiversity, pollutant discharge, environmental investment, and impact assessment; basic human rights are divided into two second-level criteria levels: health and salary and benefits, training and development; product liability is divided into three second-level criteria levels: customer rights protection, product service, and supplier evaluation; fair operation is divided into three second-level criteria levels: anti-corruption measures, compliance and law-abiding, and grievance mechanisms; community development is divided into four second-level criteria levels: community participation, health education and culture, skill development and employment, wealth and income. Relevant evaluation indicators under each level 
of the second-level standard are established. These evaluation indicators should be representative, judging, and distinguishable and fully reflect the good performance of the responsibility under the standard level, such as governance structure guidelines. This study constructs the evaluation index system which includes qualitative and quantitative, financial and non-financial indicators according to the characteristics of transportation industry. Good financial performance directly affects the performance of corporate social responsibility. Only with good support of fund chain can it ensure its development and operation. Transportation industry belongs to capital intensive industry, so it is necessary to set up indicators such as "total asset return rate"; because of the particularity of the profession of the employees in the transportation industry, the proportion of male employees is larger than that of female employees, so the index of "equal employment and elimination of discrimination" is set to measure its equal employment status; because recycling materials are an important measure of environmental protection in transportation industry, recycling materials can be used as packaging and transportation materials, which can not only contribute to environmental protection but also reduce the operating cost of enterprises, so the indicator "use of recycled recreation" is set up; because of the transportation, recycling materials are an important measure of environmental protection The industry needs customers to use personal information to purchase bills, and personal information is easily disclosed, so the indicator "customer information security mechanism" is set up; because the audience of transportation industry is wide, customers require a variety of requirements. For high-end customers, their demand for service is high efficiency, comfort, and speed. For the middle and low-end customers, the service price performance is more important, so the indicator "whether to provide personalized service" is set; because the transportation industry does not fully realize the unmanned driving stage, the quality of employees directly determines the level of customer service, so the indicator "performance and professional development evaluation" is set. According to the principle of observability, the index of audition that cannot be obtained from the data is deleted to ensure that the index after preliminary screening can be quantified, and 112 index layers are finally established.

\subsection{Data Collection and Standardization}

\subsubsection{Data Acquisition}

Many companies respond to stakeholder expectations by publishing annual CSR reports, which also deliver activities and strategies to address social and environmental issues [92]. This article uses various channels, such as Juchao Information, Oriental Wealth, corporate website, and MQI, to find out the CSR reports, sustainability reports, and social, environmental, and governance reports of all listed companies in the transportation industry in 2018 (as of July) reports. If the company only releases one type of report, the report is the main one. If the company releases the above-mentioned multiple reports, all reports should be integrated for judgment.

We carefully read all the reports of each listed company and compare them with the indicator system table of CSR performance evaluation made in the previous chapter to find out whether the criteria in the table are mentioned in the report and score the indicators in each criterion layer according to the indicator scoring standards. The scoring standards are roughly as follows:

- $\quad$ For qualitative indicators, no disclosure or explanation in the report will be scored 0 points; mentioning in the report but not clear and not detailed scores between 0.25 and 0.75 points; the complete and clear explanation in the report scores 1 point.

- For directional indicators, the data of relevant indicators in the report can be directly recorded as the score. If there is no disclosure in the report, the negative indicator takes the maximum value in the score of the indicator of all enterprises, and the positive indicator takes the minimum value in the score of the indicator of all enterprises. 
The above-mentioned data acquisition process mainly uses data mining and text analysis methods. The reason for using these two methods is that the data obtained in this way is accurate, true, reasonable, and available. Through the above process, we have obtained the complete score data of various indicators of the enterprise. The acquisition of this set of data consumes a lot of energy, but it is an important part of the entire CSR report, which has made the necessary preparation for future report analysis. Without the support of data, the entire report will lack credibility and accuracy, but after all, scoring is a man-made work. Even if a detailed and reasonable scoring standard is made, it will inevitably be subjective, but the overall data is an absolute reference.

\subsubsection{Standardization of Evaluation Index Data}

To eliminate the influence of dimensions on quantitative analysis, it is necessary to standardize the original data.

\section{Standardization of positive indicators}

The larger the positive index value becomes, the better the practical performance of a certain company in the transportation industry on this index becomes. Assuming that: $P_{i j}$ is the standardized value of the $i$-th index of the $j$-th evaluation object; $V_{i j}$ be the original value of the $i$-th index of the $j$-th evaluation object; $\mathrm{n}$ is the number of objects to be evaluated. According to the standardization equation of positive indicators, $P_{i j}$ is

$$
P_{i j}=\frac{V_{i j}-\min _{1 \leq j \leq \mathrm{n}}\left(V_{i j}\right)}{\max _{1 \leq j \leq \mathrm{n}}\left(V_{i j}\right)-\min _{1 \leq j \leq \mathrm{n}}\left(V_{i j}\right)}
$$

The meaning of Equation (1) is the relative distance between the deviation of the $i$-th index value and the minimum value to the deviation of the maximum value and the minimum value. The greater the deviation becomes, the greater the distance is, and the higher the value becomes after scoring.

2. Standardization of negative indicators

The better the performance of an enterprise in the transportation industry on this indicator becomes, the smaller the negative indicator index becomes.

The standardized equation for negative indicators is:

$$
P_{i j}=\frac{\max _{1 \leq j \leq \mathrm{n}}\left(V_{i j}\right)-V_{i j}}{\max _{1 \leq j \leq \mathrm{n}}\left(V_{i j}\right)-\min _{1 \leq j \leq \mathrm{n}}\left(V_{i j}\right)}
$$

The symbols of the above two equations have the same meaning. The meaning of Equation (2) is that the relative distance between the deviation of the maximum value of the index and the $i$-th index value is relative to the deviation of the maximum value and the minimum value. The greater the deviation is, the greater the distance is, and the higher the value becomes after scoring.

\subsection{Construction Methods of Index System}

\subsubsection{The First Index Screening Based on "R Clustering"}

$\mathrm{R}$ clustering analysis is a type of cluster analysis, which is generally used to classify indicators. In daily work, to avoid missing some important factors, when choosing indicators, we often consider relevant factors as comprehensively as possible, but the result is that there are too many variables, which brings a lot of inconvenience to statistical analysis. Therefore, we introduce $\mathrm{R}$ clustering analysis, which is to classify variables. The main function of $\mathrm{R}$ clustering analysis is to get the closeness or distance of each variable or variable group.

The purpose of R clustering is to determine the type and quantity of indicators within each criterion layer. First, R clustering is used to classify the indicators in each criterion layer, 
so that each category represents a different aspect, and the indicators selected from different categories will reflect different information. The selected indicators can completely cover all aspects of the criteria layer. Particularly, it is pointed out that the reason for clustering the indicators in the criterion level instead of the entire system is that the quantitative clustering method classifies the indicators according to the data relationship without considering the actual meaning of the indicators. Moreover, according to the criteria, the hierarchical clustering ensures that the indicators grouped into one category are related in meaning and avoids to cluster the indicators that have strong data correlation but no correlation into one category. In this study, the R-type hierarchical clustering of evaluation indicators was used by the sum of squared deviation method. The steps of R-type hierarchical clustering can be divided into the following steps:

Step 1: Artificially determine the number of clusters L, that is, artificially determine that $\mathrm{m}$ evaluation indicators will eventually be divided into L categories. If the following test passes, it means that the number of clusters is reasonable; otherwise, it is determined again.

Step 2: Treat each indicator as one category and divide $\mathrm{m}$ indicators into $\mathrm{m}$ categories.

Step 3: For the convenience of the narrative, the definition of the merger is given here.

The two types of indicators are artificially regarded as the same category as the merger. In the m-category indicators of Step 2, any two categories are combined into one category. According to the principle of permutation and combination, there are a total of $C_{m}^{2}=m(m-1) / 2$ merging schemes. Calculate the total sum of squared deviations $S$ of each merging plan by Equation (2), and determine the merging plan according to the smallest sum of squared deviations. In this way, the m-category indicators are divided into $m-1$ categories.

Hypothesis: Divide the m evaluation indicators into L categories; $S^{h}$ is the sum of squared deviations of the $h$ category $(h=1,2, \ldots, 1) ; m^{h}$ is the number of indicators in the $h$ category; $X_{i}^{h}$ is the standardized numerical vector of the $i$-th index of $h$-th category $\left(i=1,2, \ldots, m^{h}\right) ; \bar{X}^{h}$ is the sample mean vector of the $h$-th index, then the sum of squared deviations $S^{h}$ of the $h$-th index is

$$
S^{h}=\sum_{i=1}^{m^{h}}\left(X_{i}^{h}-\bar{X}^{h}\right)\left(X_{i}^{h}-\bar{X}^{h}\right)^{\prime}
$$

The sum of squared deviations of $\mathrm{L}$ categories $S$ is

$$
S=\sum_{h=1}^{l} \sum_{i=1}^{m^{h}}\left(X_{i}^{h}-\bar{X}^{h}\right)\left(X_{i}^{h}-\bar{X}^{h}\right)^{\prime}
$$

The effect of Equations (3) and (4): Calculate the sum of squared deviations of the $h$-th category by Equation (3), calculate the sum of squared deviations of all classes by (4), and select the minimum of Equation (4) as the goal the best merger plan.

Step 4: Repeat Step 3 until the final classification number is L determined in Step 1.

Step 5: Check the rationality of the clustering results. Perform K-W test on each type of index after clustering to judge whether the number of clusters 1 is reasonable.

The null hypothesis of K-W test is that different indicators have no significant differences in data characteristics. If the significance level of each type of index $\operatorname{Sig}>0.05$, then the null hypothesis is accepted, indicating that there is no significant difference between these indicators, and they can be clustered into one category, and the clustering results are reasonable. Otherwise, the null hypothesis is rejected, indicating that there are significant differences among such indicators, and they cannot be clustered into one category. Return to Step 1 to re-determine the number of clusters. The principle of $\mathrm{R}$ clustering is shown in Figure 1. 


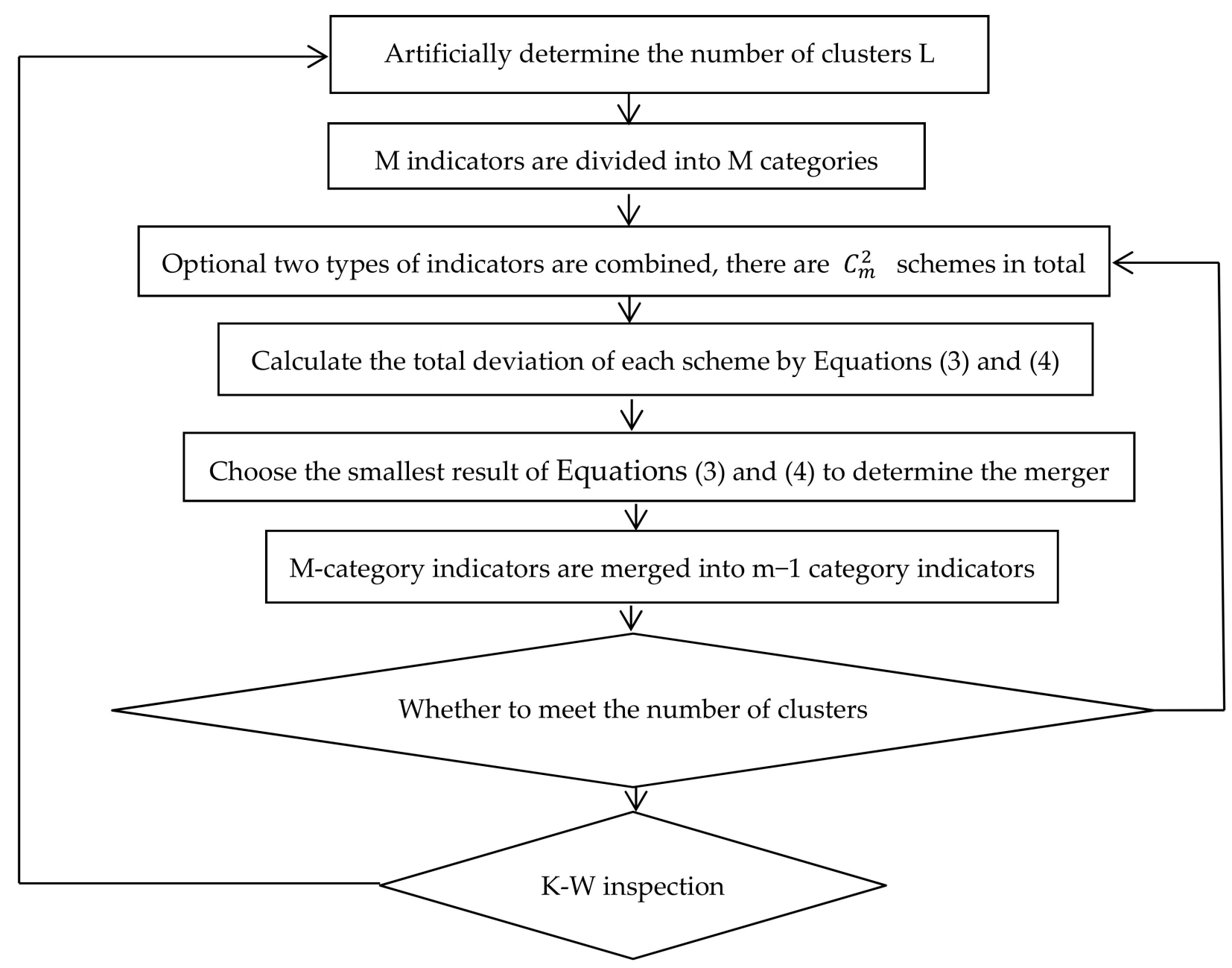

Figure 1. Principle of R clustering.

\subsubsection{The Second Screening Based on the "Coefficient of Variation" Method}

The purpose of the coefficient of variation analysis is to select effective indicators in the same type of information and delete other indicators, which not only ensures that the selected indicators have the greatest impact on the evaluation results in the category but also avoids the duplication of information in the same type of indicators.

The coefficient of variation of the indicator reflects its ability to discriminate in the evaluation. If the table coefficient of variation of an indicator is larger, it proves that the indicator's information resolving ability is stronger, and it will play a more important role in the overall evaluation. The indicator with a smaller coefficient of variation is the opposite. Therefore, if you want to ensure the simplicity and efficiency of the index system, we should delete those indicators with a small coefficient of variation that has little impact on the evaluation results. The coefficient of variation is a statistical indicator that is commonly used in economic statistics to measure data differences. The calculation equation for the coefficient of variation of the $i$-th indicator is:

$$
v_{i}=\frac{s_{i}}{X_{i}}
$$

where $X_{i}$ is the mean of the population and $S_{i}$ is the population standard deviation.

$$
X_{i}=\frac{1}{n} \sum_{j=1}^{n} X_{i j}
$$




$$
S_{i}=\sqrt{\frac{1}{N} \sum_{j=1}^{n}\left(X_{i j}-X_{i}\right)^{2}}
$$

In Equation (6), where $S_{i}$ represents the relative degree of variation of each indicator, $X_{i}$ as a reference for the degree of variation of each indicator, then Equation (7) reflects the degree of standardized variation of each indicator.

\section{Results and Discussion}

\subsection{Index Screening Based on R Clustering-Coefficient of Variation}

To facilitate understanding, the following takes the "stakeholder" secondary criterion layer as an example to carry out $\mathrm{R}$ clustering-coefficient of variation index screening.

1. Determine the number of clusters in the first level of secondary criteria. There are 5 indicators in the second-level criterion level of "stakeholders", and the number of clusters at the second-level criterion level is determined to be 4 .

2. Determine the index merger plan. Regarding 5 indicators as 4 categories and combining any two of these 5 indicators into 4 categories, we can get $C_{5}^{2}=10$ combinations; thus, there are 10 categories of 4 . The 4 categories here are any combination of two categories. In 10 categories of 4, calculate 10 Equation (2), keep the 4 categories corresponding to the smallest $S$ in Equation (2), and delete the remaining 4 categories.

3. By analogy, until the number of clusters is the determined 4 types in Step 1, the clustering results are shown in Table 1 . The first category is indicators: X1,6 identify stakeholders and $\mathrm{X} 1,8$ establish special communication channels for stakeholders. The second category is X1,7 clear stakeholders' demands. The third category is X1,9 response to interests Stakeholders' demands. The fourth category is $\mathrm{X} 1,10$ whether the report contains substantive issues. A non-parametric K-W test is performed on the first category to verify whether the number of clusters is reasonable.

4. A non-parametric $\mathrm{K}-\mathrm{W}$ test is performed on the first type of indicators to verify whether the number of clusters is reasonable. The results are shown in Table 2. Among them, the non-parametric test value is greater than the critical value, indicating that there is no significant difference between similar indicators, and the classification result is reasonable. It is pointed out that if the test result is unreasonable, you need to return to Step 1 to re-determine the number of clusters.

5. Carry out the screening of the coefficient of variation indicators, take the "stakeholder" secondary criterion level as an example, calculate the standard deviation and mean value of the scores of each indicator under the criterion level under all companies, and calculate each index variation coefficient according to Equation (3). According to the results, the index with the larger coefficient of variation in the same cluster is retained. The results are shown in Table 3.

Table 2. Clustering analysis results of "stakeholders" secondary criteria levels.

\begin{tabular}{|c|c|c|c|}
\hline Stakeholder Indicators & Clustering Categories & Nonparametric Test & $\begin{array}{l}\text { Rationality of the } \\
\text { Number of Clusters }\end{array}$ \\
\hline X1,6 Identify stakeholders & 1 & \multirow{5}{*}{0.0410} & \multirow{2}{*}{ Retain } \\
\hline $\begin{array}{l}\mathrm{X} 1,8 \text { Establish special communication } \\
\text { channels for stakeholders }\end{array}$ & 1 & & \\
\hline X1,7 Clarify stakeholder demands & 2 & & Rational \\
\hline X1,9 Respond to stakeholder appeals & 3 & & Rational \\
\hline $\begin{array}{c}\text { X1,10 Whether the report contains } \\
\text { substantive issues }\end{array}$ & 4 & & Rational \\
\hline
\end{tabular}

Finally, the screening results based on the R clustering-coefficient of variation index are obtained, as shown in Table 4. 
Table 3. Analysis results of the coefficient of variation of "stakeholders" level II criteria.

\begin{tabular}{|c|c|c|c|c|}
\hline $\begin{array}{l}\text { Secondary Criteria } \\
\text { Layers }\end{array}$ & $\begin{array}{l}\text { Governance Structure } \\
\text { Indicators }\end{array}$ & $\begin{array}{l}\text { Clustering } \\
\text { Categories }\end{array}$ & $\begin{array}{l}\text { Coefficient of } \\
\text { Variation }\end{array}$ & $\begin{array}{c}\text { Whether or Not } \\
\text { to Retain }\end{array}$ \\
\hline \multirow{5}{*}{ Stakeholders } & X1,6 Identify Stakeholders & 1 & 0.6575 & Delete \\
\hline & $\begin{array}{l}\text { X1,8 Establish special communication } \\
\text { channels for stakeholders }\end{array}$ & 1 & 0.7511 & Retain \\
\hline & X1,7 Clarify stakeholder demands & 2 & 1.0735 & Retain \\
\hline & $\mathrm{X} 1,9$ Respond to stakeholder appeals & 3 & 0.8501 & Retain \\
\hline & $\begin{array}{l}\mathrm{X} 1,10 \text { Whether the report contains } \\
\text { substantive issues }\end{array}$ & 4 & 1.1741 & Retain \\
\hline
\end{tabular}

Table 4. R clustering-coefficient of variation index screening results.

\begin{tabular}{|c|c|c|}
\hline First-Order Criteria Layers & Secondary Criteria Layers & Indicators Layers \\
\hline \multirow{8}{*}{ X1 Responsible governance } & Governance structure & $\begin{array}{l}\text { X1,5 Commitment, accountability, and importance of leadership } \\
\text { X1,7 Clarify stakeholder demands }\end{array}$ \\
\hline & Stakeholders & $\begin{array}{l}\text { X1,8 Establish special communication channels for stakeholders } \\
\text { X1,9 Respond to stakeholder appeals }\end{array}$ \\
\hline & \multirow{6}{*}{ Responsible response } & $\mathrm{X} 1,10$ Whether the report contains substantive issues \\
\hline & & X1.12 Degree of perfection of risk management control system \\
\hline & & X1,13 Explain the CSR concept or goal \\
\hline & & X1,14 Identify CSR reports \\
\hline & & $\begin{array}{l}\text { X1,15 Comply with or refer to the relevant domestic and foreign } \\
\text { standards to prepare the report }\end{array}$ \\
\hline & & X1,16 Participate in CSR related public welfare organizations \\
\hline \multirow{13}{*}{ X2 Basic human rights } & \multirow[t]{3}{*}{ Basic rights of employees } & $\begin{array}{l}\mathrm{X} 2,3 \text { The right to participate in public affairs and the right to freedom of } \\
\text { association }\end{array}$ \\
\hline & & $\begin{array}{c}\mathrm{X} 2,4 \text { The right of democratic management of employees and the } \\
\text { protection of basic rights }\end{array}$ \\
\hline & & X2,6 Whether to do maternity leave \\
\hline & \multirow[t]{3}{*}{ Employment relationship } & $\mathrm{X} 2,8$ Whether to benefit from bad labor practices \\
\hline & & X2,9 Whether to implement paid vacation \\
\hline & & $\mathrm{X} 2,10$ Equal pay for equal work \\
\hline & \multirow{4}{*}{$\begin{array}{l}\text { Health and compensation } \\
\text { and benefits }\end{array}$} & X2,13 Provide a healthy and safe working environment \\
\hline & & X2,16 Provide regular physical examination for employees \\
\hline & & $\begin{array}{l}\text { X2,17 Whether the company's labor union provides an assistance } \\
\text { mechanism for employees }\end{array}$ \\
\hline & & $\begin{array}{l}\text { X2,18 Strengthen the ability of sustainable employment and skills } \\
\text { management and provide a lifelong learning program }\end{array}$ \\
\hline & \multirow[t]{3}{*}{ Training and development } & X2,20 Performance and career development assessment \\
\hline & & $\mathrm{X} 2,21$ Establish and improve communication mechanisms \\
\hline & & X2,22 Achieve work-life balance \\
\hline \multirow{14}{*}{ X3 Environmental protection } & \multirow{5}{*}{ Resource sustainability } & X3,1 Environmentally friendly products \\
\hline & & X3,4 Comprehensive energy consumption per 10,000 yuan output value \\
\hline & & $\begin{array}{c}\text { X3,5 Degree of use of renewable materials in packaging } \\
\text { and transportation }\end{array}$ \\
\hline & & X3,7 Water consumption per unit of income \\
\hline & & $\begin{array}{c}\text { X3,8 The total amount of energy saved through energy-saving measures } \\
\text { and increased utilization efficiency }\end{array}$ \\
\hline & \multirow{2}{*}{ Biodiversity } & X3,10 Campus afforestation \\
\hline & & X3,11 Biodiversity Planning \\
\hline & & X3,12 Transportation or disposal of hazardous wastes \\
\hline & & X3,13 Reduce sewage discharge \\
\hline & Pollutant discharge & X3,14 Major pollution incident \\
\hline & & X3,16 The plan to reduce carbon emissions \\
\hline & & $\mathrm{X} 3,18$ Ten thousand yuan of output reduced greenhouse gas emissions \\
\hline & Environmental investment and & X3,19 Environmental expenditure and investment \\
\hline & impact assessment & X3,20 The number of incentives for environmental protection \\
\hline
\end{tabular}


Table 4. Cont.

\begin{tabular}{|c|c|c|}
\hline First-Order Criteria Layers & Secondary Criteria Layers & Indicators Layers \\
\hline \multirow{7}{*}{ X4 Fair operation } & Anti-corruption measures & $\begin{array}{l}\text { X4,3 The response to corruption incidents } \\
\text { X4,4 Operation point internal control evaluation implementation degree }\end{array}$ \\
\hline & \multirow{3}{*}{ The law of compliance } & $\mathrm{X} 4,6$ Number of fines and non-economic penalties \\
\hline & & X4,7 Status of Title action \\
\hline & & $\mathrm{X} 4,8$ Compliance training \\
\hline & \multirow{3}{*}{ The complaint mechanism } & X4,9 Is there an appeal body for fair operations \\
\hline & & X4,10 Appeal means \\
\hline & & X4,11 Follow-up measures to appeal incidents \\
\hline \multirow{7}{*}{ X5 Product liability } & \multirow[t]{2}{*}{ Protection of customer rights } & $\begin{array}{l}\text { X5,1 Customer complaint channel } \\
\text { X5, } 6 \text { Customer complaint handling rate }\end{array}$ \\
\hline & & $\mathrm{X} 5,7$ The number of inspections of production safety \\
\hline & \multirow{3}{*}{ Product service } & X5,8 Safety hazard correction rate \\
\hline & & $\mathrm{X} 5,10$ There is no product or service violation \\
\hline & & X5,13 Do not engage in vicious advertising competition \\
\hline & \multirow{2}{*}{ Supplier evaluation } & $\mathrm{X} 5,14$ There is no supplier access screening mechanism \\
\hline & & $\begin{array}{l}\mathrm{X} 5,15 \text { Whether to conduct comprehensive monitoring on } \\
\text { cooperating suppliers }\end{array}$ \\
\hline \multirow{7}{*}{ X6 Community development } & \multirow{2}{*}{ Community participation } & X6,1 Participate in community activities/volunteer services \\
\hline & & $\begin{array}{c}\text { X6,2 Provide appropriate financial support } \\
\text { X6,5 Join a local association }\end{array}$ \\
\hline & Health, education, culture & $\begin{array}{l}\text { X6,7 Focus on the physical and mental health of community residents } \\
\text { X6,9 Promote the development of community culture }\end{array}$ \\
\hline & \multirow{2}{*}{$\begin{array}{l}\text { Skills development and } \\
\text { employment }\end{array}$} & X6,10 Create local jobs \\
\hline & & $\mathrm{X} 6,11$ Provide skills training to community residents \\
\hline & \multirow{2}{*}{ Wealth and income creation } & X6,12 Efforts to Eradicate poverty \\
\hline & & $\mathrm{X} 6,14$ Creating an entrepreneurial environment \\
\hline \multirow{7}{*}{ X7 Economic performance } & \multirow{3}{*}{$\begin{array}{l}\text { Direct economic and social } \\
\text { contribution }\end{array}$} & X7,2 Quick ratio \\
\hline & & $X 7,6$ Rate of Payment (reflecting the payment of wages) \\
\hline & & $X 7,7$ Accounts payable turnover rate \\
\hline & \multirow{4}{*}{$\begin{array}{l}\text { Indirect economic and social } \\
\text { contribution }\end{array}$} & $\mathrm{X} 7,8$ Rate of tax increase \\
\hline & & X7,9 Government subsidies receivable (100 million yuan) \\
\hline & & X7,10 Endowment income ratio \\
\hline & & X7,13 Implementation of public welfare projects \\
\hline
\end{tabular}

\subsection{Index Weighting Method Based on Mean Square Error}

\subsubsection{Overview of Mean Square Error}

The mean square error is also called the standard deviation. The standard deviation is the commonest quantitative form to reflect the degree of dispersion of a set of data. It is an important indicator of accuracy and is most frequently used as a measure of the degree of statistical distribution in probability statistics. The standard deviation is defined as the arithmetic square root of the variance, which reflects the degree of dispersion between individuals in the group and the result of measuring the degree of distribution. The standard deviation is calculated by subtracting the sum of the squares of the average of this group of numbers from all the numbers, dividing the result by the number of regrouping numbers, and then taking the root of the obtained value which is the standard deviation of this group of data. In principle, the standard deviation has two properties: One is a difference between the standard deviation of a total amount or the standard deviation of a random variable, and another is the standard deviation of the number of samples in a subset. A small standard deviation means that these values are close to the mean; a large standard deviation means a large difference between most of the values and their mean values. The mean square deviation is used to assign values. 


\subsubsection{Mean Square Error Assignment}

Step 1: Find the mean square error.

Based on R clustering - coefficient of variation screening, the remaining index is obtained and the mean square error is calculated.

Suppose the average value of each index is $\mu$.

$$
\mu=\frac{1}{N} \sum_{i=1}^{N} x_{i}
$$

Let the mean square error be $\sigma$.

$$
\sigma=\sqrt{\frac{\sum_{i=1}^{N}\left(x_{i}-\mu\right)^{2}}{N}}
$$

Step 2: Normalize the variance of each indicator, and the value of each indicator after normalization is the indicator weight.

Step 3: Calculate the total score of each enterprise.

Finally, apply the equation $s_{j}=\sum_{i=1}^{m} W_{i} x_{i j}$ to calculate the total scores of each company.

\subsubsection{Analysis of Calculation Examples}

Step 1: For some indicators, the mean square error of each indicator is obtained as shown in Table 5.

\begin{tabular}{|c|c|c|c|}
\hline Indicators & $\begin{array}{c}\text { X1,5 Commitment, } \\
\text { Accountability, and } \\
\text { Importance of Leadership }\end{array}$ & $\begin{array}{c}\text { X1,7 Clarify } \\
\text { Stakeholder Demands }\end{array}$ & $\begin{array}{c}\text { X1,8 Establish Special } \\
\text { Communication } \\
\text { Channels for Stakeholders }\end{array}$ \\
\hline $\begin{array}{l}\text { Mean square } \\
\text { error }\end{array}$ & 0.32 & 0.42 & 0.40 \\
\hline Indicators & $\begin{array}{l}\text { X1,9 Responding to } \\
\text { stakeholders }\end{array}$ & $\begin{array}{l}\text { X1,11 Establish CSR risk } \\
\text { management mechanism }\end{array}$ & $\begin{array}{l}\text { X1,12 Degree of perfection of risk } \\
\text { management control system }\end{array}$ \\
\hline $\begin{array}{l}\text { Mean square } \\
\text { error }\end{array}$ & 0.39 & 0.36 & 0.35 \\
\hline
\end{tabular}

Table 5. Mean square difference of some indicators.

Step 2: Normalize the score of each indicator to obtain the weight of each indicator. The weight table of some indicators is shown in Table 6.

\begin{tabular}{|c|c|c|c|}
\hline Indicators & $\begin{array}{l}\text { X1,5 Commitment, Accountability, } \\
\text { and Importance of } \\
\text { Leadership }\end{array}$ & $\begin{array}{l}\text { X1,7 Clarify Stakeholder } \\
\text { Demands }\end{array}$ & $\begin{array}{l}\text { X1,8 Establish Special } \\
\text { Communication } \\
\text { Channels for } \\
\text { Stakeholders }\end{array}$ \\
\hline The weight & 0.0151 & 0.0196 & 0.0189 \\
\hline Indicators & $\mathrm{X} 1,9$ Respond to stakeholder appeals & $\begin{array}{l}\text { X1,11 Establish CSR risk } \\
\text { management mechanism }\end{array}$ & $\begin{array}{l}\text { X1.12 Degree of perfection of risk } \\
\text { management control system }\end{array}$ \\
\hline The weight & 0.0183 & 0.0169 & 0.0166 \\
\hline
\end{tabular}

Table 6. Weight of some indicators.

Step 3: Obtain the total scores and ranking of the company through the score and weight of each indicator of each company. 


\subsection{Results Analysis}

As of 20 July 2018, a total of 74 listed companies in the transportation industry have released 2018 CSR reports. This paper makes a reasonable evaluation and scoring of the CSR performance of these 74 listed companies. The overall CSR performance scores and rankings of 74 companies are shown in Table 7.

Table 7. Scores and ranking of Corporate social responsibility (CSR) performance of listed companies in the transportation industry in 2018.

\begin{tabular}{|c|c|c|c|c|c|c|c|}
\hline Ranking & The Enterprise Name & Scores & $\begin{array}{l}\text { Centesimal } \\
\text { System }\end{array}$ & Ranking & The Enterprise Name & Scores & $\begin{array}{c}\text { Centesimal } \\
\text { System }\end{array}$ \\
\hline 1 & CIMC & 0.6623 & 66.23 & 38 & SF Express & 0.3541 & 35.41 \\
\hline 2 & Qingdao Port & 0.6598 & 65.98 & 39 & SIPG & 0.3522 & 35.22 \\
\hline 3 & China Southern Airlines & 0.5682 & 56.82 & 40 & PDA & 0.3498 & 34.98 \\
\hline 4 & AIR CHINA & 0.5248 & 52.48 & 41 & CATHAY PACFIC & 0.3485 & 34.85 \\
\hline 5 & CMG & 0.5170 & 51.70 & 42 & Zhejiang Expressway & 0.3457 & 34.57 \\
\hline 6 & CISCO SHIPPING & 0.5138 & 51.38 & 43 & Johnson Holdings & 0.3406 & 34.06 \\
\hline 7 & Xiamen Port & 0.5137 & 51.37 & 44 & YTO International & 0.3063 & 30.63 \\
\hline 8 & BCIA & 0.5045 & 50.45 & 45 & Transport International & 0.2992 & 29.92 \\
\hline 9 & $\begin{array}{l}\text { COSCO SHIPPING } \\
\text { Energy Transportation }\end{array}$ & 0.5039 & 50.39 & 46 & Yantian Port & 0.2934 & 29.34 \\
\hline 10 & Jiangsu Expressway & 0.4934 & 49.34 & 47 & MTR & 0.2934 & 29.34 \\
\hline 11 & $\begin{array}{l}\text { COSCO SHIPPING } \\
\text { Specialized Carriers }\end{array}$ & 0.4884 & 48.84 & 48 & Lianyungang Port & 0.2929 & 29.29 \\
\hline 12 & CMAL & 0.4795 & 47.95 & 49 & Dragon Crown & 0.2924 & 29.24 \\
\hline 13 & Anhui Expressway & 0.4787 & 47.87 & 50 & Jinzhou Port & 0.2888 & 28.88 \\
\hline 14 & COSCO SHIPPING Ports & 0.4750 & 47.50 & 51 & Daqin Railway & 0.2827 & 28.27 \\
\hline 15 & Yueyun Transportation & 0.4605 & 46.05 & 52 & Tangshan Port & 0.2775 & 27.75 \\
\hline 16 & OOIL & 0.4577 & 45.77 & 53 & KLN & 0.2746 & 27.46 \\
\hline 17 & QHD Port & 0.4514 & 45.14 & 54 & Ningbo Marine & 0.2726 & 27.26 \\
\hline 18 & China Eastern Airlines & 0.4452 & 44.52 & 55 & Hainan Airlines & 0.2705 & 27.05 \\
\hline 19 & Shenzhen Expressway & 0.4383 & 43.83 & 56 & Dazhong Transportation & 0.2704 & 27.04 \\
\hline 20 & Sinotrans & 0.4372 & 43.72 & 57 & Pacific Basin & 0.2623 & 26.23 \\
\hline 21 & STO Express & 0.4290 & 42.90 & 58 & Ningbo Zhoushan Port & 0.2610 & 26.10 \\
\hline 22 & $\begin{array}{c}\text { China Development Bank } \\
\text { Leasing }\end{array}$ & 0.4269 & 42.69 & 59 & Jiangxi Changyun & 0.2590 & 25.90 \\
\hline 23 & YTO EXPRESS & 0.4251 & 42.51 & 60 & YUNDA EXPRESS & 0.2529 & 25.29 \\
\hline 24 & Tielong Logistics & 0.4238 & 42.38 & 61 & Heilongjiang Transport & 0.2523 & 25.23 \\
\hline 25 & CMSTD & 0.4161 & 41.61 & 62 & Worldgate Express & 0.2406 & 24.06 \\
\hline 26 & Shenzhen International & 0.4152 & 41.52 & 63 & Shanghai Shentong Metro & 0.2402 & 24.02 \\
\hline 27 & Daido Group & 0.4146 & 41.46 & 64 & Yingkou Port & 0.2279 & 22.79 \\
\hline 28 & Rizhao Port & 0.4109 & 41.09 & 65 & Deppon Express & 0.2186 & 21.86 \\
\hline 29 & $\begin{array}{l}\text { COSCO SHIPPING } \\
\text { Development }\end{array}$ & 0.3961 & 39.61 & 66 & Shandong Expressway & 0.2163 & 21.63 \\
\hline 30 & Tianjin Port & 0.3907 & 39.07 & 67 & $\begin{array}{l}\text { Henan Zhongyuan } \\
\text { Expressway }\end{array}$ & 0.2025 & 20.25 \\
\hline 31 & Singamas & 0.3894 & 38.94 & 68 & Fujian Expressway & 0.1784 & 17.84 \\
\hline 32 & CKSG & 0.3850 & 38.50 & 69 & $\begin{array}{l}\text { Delixi Xinjiang } \\
\text { Transportation }\end{array}$ & 0.1574 & 15.74 \\
\hline 33 & GUANGSHEN Railway & 0.3818 & 38.18 & 70 & $\begin{array}{l}\text { Jiangxi Ganyue } \\
\text { Expressway }\end{array}$ & 0.1569 & 15.69 \\
\hline 34 & World-link Logistics & 0.3799 & 37.99 & 71 & Jilin Expressway & 0.1480 & 14.80 \\
\hline 35 & $\begin{array}{l}\text { Yuexiu Transport } \\
\text { Infrastructure }\end{array}$ & 0.3748 & 37.48 & 72 & $\begin{array}{l}\text { Jinhui Shipping and } \\
\text { Transportation }\end{array}$ & 0.1212 & 12.12 \\
\hline 36 & Sichuan Expressway & 0.3707 & 37.07 & 73 & Huayu Expressway & 0.1190 & 11.90 \\
\hline 37 & Guangzhou Port & 0.3596 & 35.96 & 74 & Baiyun Airport & 0.0828 & 8.28 \\
\hline
\end{tabular}

As shown in Table 7, the results of the study show that CIMC and Qingdao Port rank the top two among all companies and are the only two companies that score above 60 points. Among the scores of these two companies, the relevant indicators of the green 
supply chain score higher, and they actively assume the responsibilities to stakeholders in the supply chain, including environmental responsibility, product responsibility, and responsibility to supply chain partners. According to the survey of transportation behavior of Chinese urban residents, green travelers who care about the environment and have a positive environmental attitude are more willing to choose green public transportation [93]. Obviously, the performance of these two companies meets the requirements of China's green travelers to choose transportation and can also meet the requirements of different stakeholders, and the scores are also in line with China's reality. In contrast, Baiyun Airport can only get 8.28 points, which is 57.95 points away from the highest scored CIMC Group. This shows that different companies in the transportation industry still have a large gap in the performance of social responsibility in the green supply chain. This may be because the sub-sectors of each company in the transportation industry have a large span, such as railways, waterways, aviation, high-speed, etc., which have different characteristics among each other, which leads to differences in the performance of corporate social responsibilities [64]. It is worth noting that only two companies achieved a "pass" performance score, which means that the whole transportation industry still has many shortcomings in terms of green supply chain CSR, and there is still a lot of room for improvement. This is consistent with Gao et al.'s CSR analysis of China's top 100 companies in 2007 [23]. In their research, compared with the top 100 Chinese companies in other industries, the transportation industry is less concerned about all issues.

From the perspective of the sub-sectors of China's transportation industry, among the top ten companies this year, companies in the air transportation industry and port transportation industry account for more. These two industries have performed well in the indicators of social responsibility in the green supply chain and can serve as benchmarks for the entire transportation industry. The main reason is that these two sub-sectors have a large market extension, a high degree of nationalization, and fierce market competition [94]. In contrast, the problems in the performance of the duties of the entire transportation industry are reflected in the bottom ten enterprises. It is worth mentioning that among these companies, the expressway transportation industry accounts for half, which reflects that the overall performance of this industry is not optimistic. Checking their reports shows that there are still many problems to be solved, and many aspects need to be improved. The reason is mainly due to the relative monopoly of the industry, strong regionality, and low market competition [94]. The difference in CSR performance of subsectors can be explained by Macdonald's CSR stakeholder influence dynamic model, that is, consumer market, NGO, and financial market pressure will affect the fulfillment of social responsibilities [95]. However, this year, 37 companies score higher than the industry average, accounting for half of the total number of companies. This means that the overall development of CSR in the transportation industry supply chain is improving. All in all, the social responsibility performance of the supply chain in China's transportation industry is poor, and the entire industry needs to work together to improve the level of green supply chain management and improve the overall CSR performance. Although the development of social responsibility of listed companies in the industry is still uneven, the gap is gradually narrowing. The corporate green supply chain social responsibility of China's transportation industry is still in the preliminary stage of development [94].

Through the above analysis, this paper provides some enlightenment. First, the government strengthens the legislative work of CSR, especially the CSR of green supply chain management. The Chinese government should formulate certain laws and regulations to put forward the requirements for enterprises to disclose CSR information and urge enterprises to perform social responsibilities following with the requirements of the state through the inspection, guidance, and restraint of laws and regulations. Second, companies should establish a green supply chain CSR concept and strengthen their sense of responsibility. Companies in the transportation industry should take the lead in actively fulfilling their social responsibilities, establish a correct sense of responsibility, and promote the development of CSR throughout the industry. For example, the establishment of a special 
CSR department within the enterprise, which is incorporated into the daily business life and benefit evaluation of the enterprise, encourages the enterprise to actively perform CSR. The third is that companies should accurately make up for their shortcomings to eliminate polarization. From the conclusions, it can be noted that the differences in the performance of social responsibilities among companies in the transportation industry are also obvious, and even their polarization. Therefore, companies that perform poorly should learn from "benchmark" companies that perform well, recognize their shortcomings, and work hard. To narrow the gap, for example, the transportation equipment industry should learn from CIMC's experience and strive for better development in the future.

\section{Conclusions}

This paper, from the perspective of green supply chain management, uses the "R clustering-variation coefficient analysis" method and establishes a responsibility evaluation system for listed companies in China's transportation industry. The evaluation system is applied to 74 listed transportation companies in China, using the mean square error index weighting method to assign weights, and a comparative analysis of subsectors in the transportation industry is carried out. Besides, the main contributions of this article are to (1) provide a reference for CSR/CSP research in developing countries and emerging markets and (2) employ empirical research methods to establish CSR assessment framework in the green supply chain of the transportation industry, which provides clues for companies in the transportation industry to pursue SC-CSR and at the same time makes up for the shortcomings of insufficient empirical research in the literature on SC-CSR [16].

This study is not without some limitations. The CSR evaluation system designed in this paper is established for China's transportation industry, which may limit the universality and applicability of the evaluation system in this paper. Besides, the data of some private enterprises and foreign enterprises are not easy to obtain, and the selected companies are listed in China. Therefore, the evaluation system designed is not necessarily applicable to private enterprises and foreign enterprises in China's transportation industry.

It is necessary for future research to develop a brand-new method to properly handle some valuable but difficult to obtain and inappreciable indicators to improve the existing performance evaluation system. Secondly, the main evaluation materials in this article come from the CSR report, with other materials, such as Information disclosed by the company's official website or news media, as supplementary materials. Therefore, for some companies that have not released CSR reports but perform well in various aspects, how to evaluate their CSR performance has become the content of the next step of research.

Author Contributions: Conceptualization, H.K.; data curation, J.L.; formal analysis, J.L.; methodology, J.L.; project administration, H.K.; supervision, H.K.; writing—original draft, J.L.; writing—review and editing, M.B. All authors have read and agreed to the published version of the manuscript.

Funding: This research was funded by Project of Dalian Federation of Social Sciences in 2020 (grant number2020dlskzd123); National Natural Science Foundation of China (grant number J2024024; 71831002;71672016;72072018) and the Fundamental Research Funds for the Central Universities (grant number 3132019501); Changjiang Scholars and Innovation Team Development Program [IRT_17R13].

Institutional Review Board Statement: Not applicable. This study is not involving humans or animals. Informed Consent Statement: Not applicable. This study is not involving humans.

Data Availability Statement: Not applicable

Conflicts of Interest: The authors declare no conflict of interest.

\section{References}

1. KLD Research \& Analytics. Domini 400 Social Index. 1990. Available online: https://www.msci.com/msci-kld-400-social-index (accessed on 20 July 2018).

2. The United Nations. The Global Compact. 1995. Available online: https:/ / www.unglobalcompact.org/ (accessed on 20 July 2018). 
3. Social Accountability International. Social Accountability 8000 International Standard. 2010. Available online: https://sa-intl. org/resources/sa8000-getting-started/ (accessed on 20 July 2018).

4. International Standard Organization. ISO 26000. 2010. Available online: https://www.iso.org/standard/42546.html (accessed on 20 July 2018).

5. Global Reporting Initiative (GRI). The Global Reporting Initiative Sustainability Reporting Guidelines (GRI4.0). 2015. Available online: https: / / www.globalreporting.org/standards/download-the-standards / (accessed on 20 July 2018).

6. Ip, P.K. Corporate Social Responsibility and Crony Capitalism in Taiwan. J. Bus. Ethics 2008, 79, 167-177. [CrossRef]

7. Material and Quantitative Indicators Database. Material and Quantitative Indicators Guide. Available online: http://mqien. syntao.com/MQI_Downloads.asp (accessed on 20 July 2018).

8. Guidance on Social Responsibility Reporting. Available online: http://www.gb688.cn/bzgk/gb/newGbInfo?hcno=611424A173 24900421D07602A5D1030E (accessed on 20 July 2018).

9. Hong Kong Stock Exchange. The Environmental, Social and Governance Reporting Guidelines. Available online: https://www. hkex.com.hk/?sc_lang=en (accessed on 20 July 2018).

10. Nalebuff, B.; Brandenburger, A. Coopetition: A Revolutionary Mindset that Combines Competition and Cooperation in the Market Place; Doubleday Press: New York, NY, USA, 1996.

11. Zadek, S. The Path to Corporate Responsibility. Harv. Bus. Rev. 2004, 82, 125-132.

12. Mamic, I. Managing global supply chain: The sports footwear, apparel and retail sectors. J. Bus. Ethics 2005, 59, 81-100. [CrossRef]

13. Jørgensen, H.B.; Pruzan-Jørgensen, P.M.; Jungk, M.; Cramer, A. Strengthening Implementation of Corporate Social Responsibility in Global Supply Chains; World Bank: Washington, DC, USA, 2003.

14. Radin, T.J. The effectiveness of global codes of conduct: Role models that make sense. Bus. Soc. Rev. 2004, 109, 415-447. [CrossRef]

15. Hervani, A.A.; Helms, M.M. Performance measurement for green supply management. Benchmarking Int. J. 2005, 12, 330-353. [CrossRef]

16. Feng, Y.T.; Zhu, Q.H.; Lai, K.H. Corporate Social Responsibility for Supply Chain Management: A Literature Review and Bibliometric Analysis. J. Clean. Prod. 2017, 158, 296-307. [CrossRef]

17. Reefke, H.; Sundaram, D. Key themes and research opportunities in sustainable supply chain management-Identification and evaluation. Omega-Int. J. Manag. 2017, 66, 195-211. [CrossRef]

18. Carter, C.R.; Jennings, M. The role of purchasing in the socially responsible management of the supply chain: A structural equation analysis. J. Bus. Logist. 2004, 25, 145-186. [CrossRef]

19. Emmelhainz, M.A.; Adams, R.J. The Apparel Industry Response to "Sweatshop" Concerns: A Review and Analysis of Codes of Conduct. J. Supply Chain Manag. 1999, 35, 51-57. [CrossRef]

20. Carter, C.R. Purchasing and Social Responsibility: A Replication and Extension. J. Supply Chain Manag. 2004, 40, 4-16. [CrossRef]

21. Dao, V.; Langella, I.; Carbo, J. From green to sustainability: Information Technology and an integrated sustainability framework. J. Strateg. Inf. Syst. 2011, 20, 63-79. [CrossRef]

22. Vidal, N.; Kozak, R.; Hansen, E. Adoption and implementation of corporate responsibility practices: A proposed framework. Bus. Soc. 2015, 54, 701-717. [CrossRef]

23. Gao, Y. Corporate Social Performance in China: Evidence from Large Companies. J. Bus. Ethics 2009, 89, 23-35. [CrossRef]

24. Elkington, J. Cannibals with Forks: The Triple Bottom Line of 21st Century Business; John Wiley \& Son Ltd. (Import): Capstone, Oxford, UK, 1997.

25. Whetten, D.A.; Rands, G.; Godfrey, P. What are the Responsibilities of Business to Society? In Handbook of Strategy and Management; Pettigrew, A., Thomas, H., Whittington, R., Eds.; SAGE Publications Ltd.: London, UK, 2006; pp. $373-409$.

26. Freeman, R.E. Strategic Management: A Stakeholder Approach; Pitman Publishing Inc.: Boston, MA, USA, 1984.

27. Freeman, R.E. Managing for stakeholders: Trade-offs or value creation. J. Bus. Ethics 2010, 96, 7-9. [CrossRef]

28. Ackermann, F.; Eden, C. Strategic management of stakeholders: Theory and practice. Long Range Plan. 2011, 44, 179-196. [CrossRef]

29. Arli, D.I.; Lasmono, H.K. Consumers' perception of corporate social responsibility in a developing country. Int. J. Consum. Stud. 2010, 34, 46-51. [CrossRef]

30. Egbeleke, A.A. Strategic corporate responsibility and sustainability performance management model. J. Manag. Sustain. 2014, 4, 92-105. [CrossRef]

31. Hooghiemstra, R. Corporate communication and impression management: New perspective why companies engage in Corporate Social Reporting. J. Bus. Ethics 2000, 27, 55-68. [CrossRef]

32. Branco, M.C.; Rodrigues, L.L. Factors influencing social responsibility disclosure by Portuguese companies. J. Bus. Ethics 2008, 83, 685-701. [CrossRef]

33. Hasseldine, J.; Salama, A.I.; Toms, J.S. Quantity Versus Quality: The Impact of Environmental Disclosures on the Reputations of UK PLCS. Br. Account. Rev. 2005, 37, 231-248. [CrossRef]

34. Gavana, G.; Gottardo, P.; Moisello, A.M. Do customers value CSR disclosure? Evidence from Italian family and non-family firms. Sustainability 2018, 10, 1642. [CrossRef]

35. Matten, D.; Crane, A.; Chappie, W. Behind the Mask: Revealing the True Face of Corporate Citizenship. J. Bus. Ethics 2003, 45, 109-120. [CrossRef]

36. Carroll, A.B. A three-dimensional conceptual model of corporate performance. Acad. Manag. Rev. 1979, 4, 497-505. [CrossRef] 
37. Waddock, S.A.; Graves, S.B. The corporate social performance-financial performance link. Strateg. Manag. J. 1997, 18, 303-319. [CrossRef]

38. Dabija, D.C.; Băbu ${ }_{s}$, R. Empirical Study on the Impact of Service, Communication and Corporate Social Responsability on the Image of Romanian Retail Brands. Procedia Soc. Behav. Sci. 2014, 109, 906-912. [CrossRef]

39. Luo, X.; Wang, H.; Raithel, S.; Zheng, Q. Corporate social performance, analyst stock recommendations, and firm future returns. Strateg. Manag. J. 2015, 36, 123-136. [CrossRef]

40. Wartick, S.L.; Cochran, P.L. The evolution of the corporate social performance model. Acad. Manag. Rev. 1985, 10, 758-769. [CrossRef]

41. De Colle, S. CSR and management systems. In Corporate Social Responsibility: Concepts, Accountability and Reporting; Alluche, J., Ed.; Palgrave MacMillan: New York, NY, USA, 2006; pp. 333-353.

42. Crian-Mitra, C.S.; Stanca, L.; Dabija, D.C. Corporate Social Performance: An Assessment Model on an Emerging Market. Sustainability 2020, 12, 4077. [CrossRef]

43. Chang, Y.H.; Yeh, C.H. Managing Corporate Social Responsibility Strategies of Airports: The Case of Taiwan's Taoyuan International Airport Corporation. Transp. Res. Part A Policy Pract. 2016, 92, 338-348. [CrossRef]

44. Williams, P.; Naumann, E. Customer satisfaction and business performance: A firm-level analysis. J. Serv. Mark. 2011, 25, 20-32. [CrossRef]

45. Buller, P.; McEvoy, G. Strategy, human resource management and performance: Sharpening line of sight. Hum. Resour. Manag. Rev. 2012, 22, 43-56. [CrossRef]

46. Saeidi, S.P.; Sofian, S.; Saeidi, P.; Saeidi, S.P.; Saeidi, S.A. How does corporate social responsibility contribute to firm financial performance? The mediating role of competitive advantage, reputation, and customer satisfaction. J. Bus. Res. 2015, 68, 341-350. [CrossRef]

47. Anser, M.K.; Zhang, Z.; Kanwal, L. Moderating effect of innovation on corporate social responsibility and firm performance in realm of sustainable development. Corp. Soc. Responsib. Environ. Manag. 2018, 25, 799-806. [CrossRef]

48. McGuire, J.B.; Sundgren, A.; Schneeweis, T. Corporate social responsibility and firm financial performance. Acad. Manag. J. 1988, $31,854-872$.

49. Riahi-Belkaoui, A. Executive compensation, organisational effectiveness, social performance and firm performance: An empirical investigation. J. Bus. Financ. Account. 1992, 19, 25-38. [CrossRef]

50. Aupperle, K.E.; Van Pham, D. An Expanded Investigation in the Relationship between Corporate Social Responsibility and Profitability. Acad. Manag. J. 1989, 2, 263-274.

51. Lee, S.; Kwanglim, S.; Amit, S. Corporate social responsibility and firm performance in the airline industry: The moderating role of oil prices. Tour. Manag. 2013, 38, 20-30. [CrossRef]

52. Brik, A.B.; Rettab, B.; Mellahi, K. Market orientation, corporate social responsibility, and business performance. J. Bus. Ethics 2011, 99, 307-324. [CrossRef]

53. Zhao, T.; Xiao, X.; Zhang, B.S. The Dynamic Effect of Corporate Social Responsibility on Capital Allocation Efficiency-Based on the Moderating Effects of Corporate Governance. J. Shanxi Financ. Econ. Univ. 2018, 40, 66-80. (In Chinese)

54. Luo, J.; Kuang, H.; Shen, S. Impact of corporate social responsibility on financial performance by taking the transportation industry as an example. Sci. Res. Manag. 2019, 40, 199-208. (In Chinese)

55. Wickert, C.; de Bakker, F. Pitching for social change: Toward a relational approach to selling and buying social issues. Acad. Manag. Discov. 2018, 4, 50-73. [CrossRef]

56. Abbott, W.F.; Monsen, R.J. On the measurement of corporate social responsibility: Self-reported disclosures as a method of measuring corporate social involvement. Acad. Manag. J. 1979, 22, 501-515.

57. Porter, M.E.; Kramer, M.R. Strategy and Society: The Link between Competitive Advantage and Corporate Social Responsibility. Harv. Bus. Rev. 2006, 84, 78-92.

58. Costa, R.; Menichini, T. A multidimensional approach for CSR assessment: The importance of the stakeholder perception. Expert Syst. Appl. 2013, 40, 150-161. [CrossRef]

59. Wang, Y.-L.; Shen, K.-Y.; Huang, J.-Y.; Luarn, P. Use of a Refined Corporate Social Responsibility Model to Mitigate Information Asymmetry and Evaluate Performance. Symmetry 2020, 12, 1349. [CrossRef]

60. Abreu, R.; David, F.; Crowther, D. Corporate Social Responsibility in Portugal Empirical Evidence of Corporate Behavior. Corp. Gov. 2005, 5, 3-18. [CrossRef]

61. Maignan, I. 'Consumers' Perceptions of Corporate Social Responsibilities: A Cross-Cultural Comparison. J. Bus. Ethics 2001, 30, 57-72. [CrossRef]

62. Chen, J.; Huang, Q.; Peng, H.; Zhong, H. Research Report on Corporate Social Responsibility of China; Springer: Berlin/Heidelberg, Germany, 2015.

63. Qi, L.; Shang, K.; Wang, W. A research on construction of social responsibility performance evaluation system of transportation enterprises. Sci. Res. Manag. 2018, 39, 102-112. (In Chinese)

64. Meng, B.; Shen, S.; Kuang, H.; Li, F.; Feng, H. Evaluating Model of Corporate Social Responsibility Based on Fuzzy Topsis: Taking Transportation Industry as Example. Manag. Rev. 2019, 31, 191-202. (In Chinese)

65. Min, S.; Mentzer, J.T. Developing and Measuring Supply Chain Management Concepts. J. Bus. Logist. 2004, 25, 63-99. [CrossRef]

66. Bechtel, C.; Jayaram, J. Supply Chain Management: A Strategic Perspective. Int. J. Logist. Manag. 1997, 8, 15-34. [CrossRef] 
67. Pettit, T.; Croxton, K.L.; Fiksel, J. Ensuring Supply Chain Resilience: Development and implementation of an assessment tool. J. Bus. Logist. 2013, 34, 46-76. [CrossRef]

68. Clements, M.D.; Dean, D.L.; Cohen, D.A. Proposing an operational classification scheme for embryonic cooperative relationship levels. J. Manag. Organ. 2007, 13, 51-64. [CrossRef]

69. Council of Supply Chain Management Professionals. CSCMP Supply Chain Management Definitions. 2009. Available online: https:/ / cscmp.org/CSCMP/Educate/SCM_Definitions_and_Glossary_of_Terms/ (accessed on 30 December 2020).

70. Bowrey, G.; Clements, M. Supply Chain Legitimation through CSR Reporting. Australas. Account. Bus. Financ. J. 2019, 13, 27-43. [CrossRef]

71. Monczka, R.M.; Morgan, J. What's Wrong with Supply Chain Management? Purchasing 1997, 122, 69-73.

72. Giannakis, M.G.; Croom, S.R. Toward the Development of a Supply Chain Management Paradigm: A Conceptual Framework. J. Supply Chain Manag. 2004, 40, 27-37. [CrossRef]

73. Ellram, L.M.; Cooper, M.C. Supply Chain Management: It's all about the journey, not the destination. J. Supply Chain Manag. 2013, 50, 8-20. [CrossRef]

74. Svensson, G. Aspects of sustainable supply chain management: Conceptual framework and empirical example. Supply Chain Manag. Int. J. 2007, 12, 262-266. [CrossRef]

75. Van Hoek, R.I.; Erasmus. From reversed logistics to green supply chains. Logist. Solut. Issue 2000, 2, 28-33. [CrossRef]

76. Zhu, Q.; Sarkis, J.; Lai, K.H. Confirmation of a measurement model for green supply chain management practices implementation. Int. J. Prod. Econ. 2008, 111, 261-273. [CrossRef]

77. Sathiya, V.; Chinnadurai, M.; Ramabalan, S.; Appolloni, A. Mobile robots and evolutionary optimization algorithms for green supply chain management in a used-car resale company. Environ. Dev. Sustain. 2020, 1-29. [CrossRef]

78. Murphy, P.R.; Poist, R.F. Socially Responsible Logistics: An Exploratory Study. Transp. J. 2002, 41, 23-35.

79. Poist, R.F. Evolution of Conceptual Approaches to the Design of Logistics System: A Sequel. Transp. J. 1989, $28,35-39$.

80. Carter, C.R.; Jennings, M.M. Social Responsibility and Supply Chain Relationships. Transp. Res. 2002, 38, 37-52. [CrossRef]

81. Carter, C.R.; Jennings, M.M. Logistics Social Responsibility: An Integrative Framework. J. Bus. Logist. 2002, 23, 145-180. [CrossRef]

82. Carter, C.R.; Rogers, D.A. framework of sustainable supply chain management: Moving toward new theory. Int. J. Phys. Distrib. Logist. Manag. 2005, 38, 360-387. [CrossRef]

83. Andersen, M.; Skjoett-Larsen, T. Corporate social responsibility in global supply chains. Supply Chain Manag. Int. J. 2009, 14, 75-86. [CrossRef]

84. Tate, W.L.; Ellram, L.M.; Kirchoff, J.F. Corporate social responsibility reports: A thematic analysis related to supply chain management. J. Supply Chain Manag. 2010, 46, 19-44. [CrossRef]

85. Lindgreen, A.; Swaen, V.; Maon, F.; Pedersen, E.R. The many and the few: Rounding up the SMEs that manage CSR in the supply chain. Supply Chain Manag. Int. J. 2009, 14, 109-116.

86. Yoon, H.D.; Sung, J.S.; Seo, R.B. The effect of cooperate social responsibility in supply chain management (SC-CSR) on the willingness to initiate CSR in small and medium-sized enterprises. Asia Pac. J. Bus. Ventur. Entrep. 2012, 7, $25-34$.

87. Krause, D.R.; Scannell, T.V. Supplier development practices: Product- and service-based industry comparisons. J. Supply Chain 2002, 38, 13-21. [CrossRef]

88. Maloni, M.J.; Brown, M.E. Corporate social responsibility in the supply chain: An application in the food industry. J. Bus. Ethics 2006, 68, 35-52. [CrossRef]

89. Perry, P.; Towers, N. Conceptual framework development: CSR implementation in fashion supply chains. Int. J. Phys. Distrib. Logist. Manag. 2013, 43, 478-501. [CrossRef]

90. Keating, B.; Quazi, A.; Kriz, A.; Coltman, T. In pursuit of a sustainable supply chain: Insights from Westpac Banking Corporation. Supply Chain Manag. Int. J. 2008, 13, 175-179. [CrossRef]

91. Kogg, B. Responsibility in the Supply Chain: Interorganisational Management of Environmental and Social Aspects in the Supply Chain-Case Studies from the Textile Sector. Ph.D. Thesis, Lund University, Lund, Sweden, 2009.

92. Esrock, S.L.; Leichty, G.B. Social Responsibility and Corporate Web Pages: Self-Presentation or Agenda-Setting? Public Relat. Rev. 1998, 24, 305-319. [CrossRef]

93. Jia, H.; Appolloni, A.; Wang, Y. Green Travel: Exploring the Characteristics and Behavior Transformation of Urban Residents in China. Sustainability 2017, 9, 1043. [CrossRef]

94. Qi, L.; Wei, T. The performance evaluation model of corporate social responsibility based on ISO26000 standard. Sci. Res. Manag. 2013, 34, 84-92. (In Chinese)

95. Macdonald, J.B. Improving the promotion of CSR initiatives: A framework for understanding stakeholder communications from a dynamic learning perspective. Acad. Mark. Stud. J. 2010, 14, 77-93. 